\title{
Report on Design and Preliminary Data of Halden In-Pile Creep Rig
}

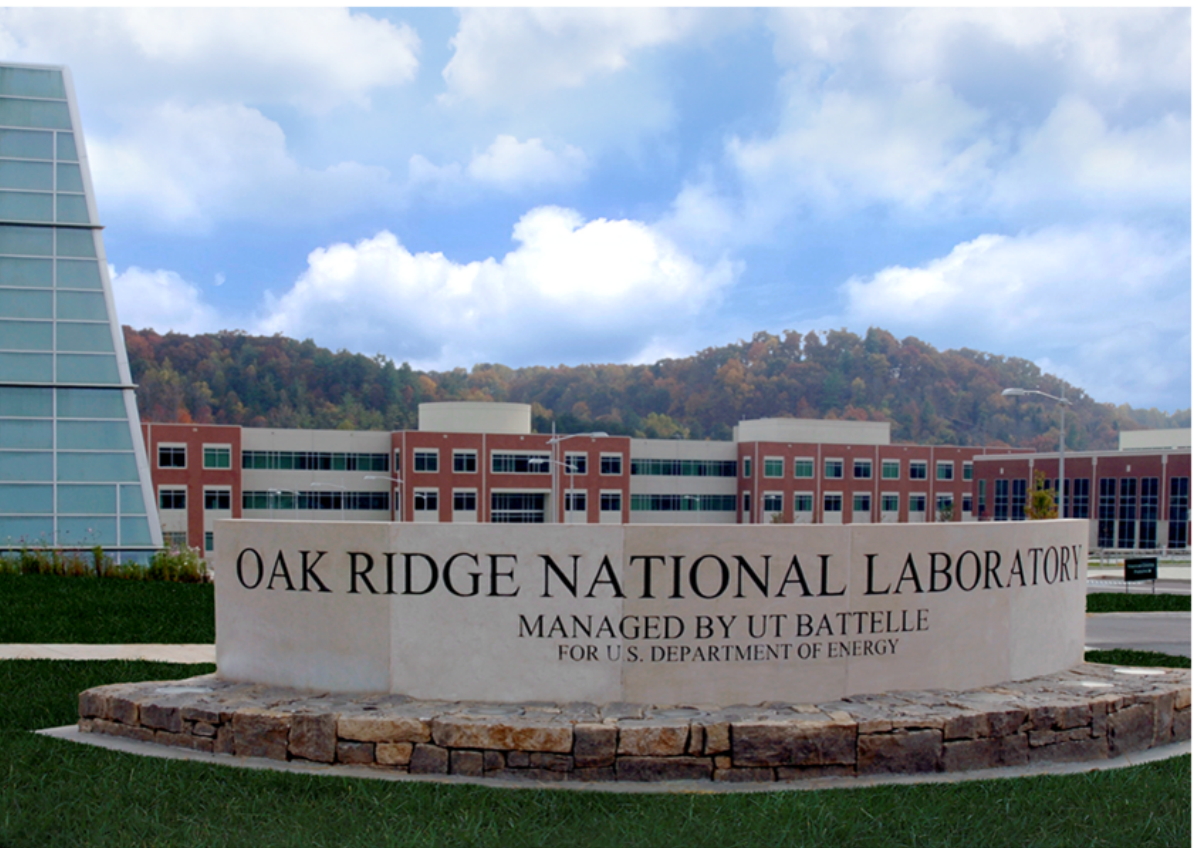

Approved for public release. Distribution is unlimited.
K. A. Terrani

T. M. Karlsen

Y. Yamamoto

September, 2015 


\title{
DOCUMENT AVAILABILITY
}

Reports produced after January 1, 1996, are generally available free via US Department of Energy (DOE) SciTech Connect.

Website http://www.osti.gov/scitech/

Reports produced before January 1, 1996, may be purchased by members of the public from the following source:

\author{
National Technical Information Service \\ 5285 Port Royal Road \\ Springfield, VA 22161 \\ Telephone 703-605-6000 (1-800-553-6847) \\ TDD 703-487-4639 \\ Fax 703-605-6900 \\ E-mail info@ntis.gov \\ Website http://www.ntis.gov/help/ordermethods.aspx
}

Reports are available to DOE employees, DOE contractors, Energy Technology Data Exchange representatives, and International Nuclear Information System representatives from the following source:

Office of Scientific and Technical Information

PO Box 62

Oak Ridge, TN 37831

Telephone 865-576-8401

Fax 865-576-5728

E-mail reports@osti.gov

Website http://www.osti.gov/contact.html

This report was prepared as an account of work sponsored by an agency of the United States Government. Neither the United States Government nor any agency thereof, nor any of their employees, makes any warranty, express or implied, or assumes any legal liability or responsibility for the accuracy, completeness, or usefulness of any information, apparatus, product, or process disclosed, or represents that its use would not infringe privately owned rights. Reference herein to any specific commercial product, process, or service by trade name, trademark, manufacturer, or otherwise, does not necessarily constitute or imply its endorsement, recommendation, or favoring by the United States Government or any agency thereof. The views and opinions of authors expressed herein do not necessarily state or reflect those of the United States Government or any agency thereof. 
Under auspices of:

U.S. Department of Energy, Office of Nuclear Energy

Fuel Cycle Research and Development Program

Advanced Fuels Campaign

\title{
REPORT ON DESIGN AND PRELIMINARY DATA OF HALDEN IN-PILE CREEP RIG
}

\author{
K. A. Terrani \\ T. M. Karlsen \\ Y. Yamamoto
}

September, 2015

Prepared by

OAK RIDGE NATIONAL LABORATORY

Oak Ridge, TN 37831-6283

managed by

UT-BATTELLE, LLC

for the

US DEPARTMENT OF ENERGY

under contract DE-AC05-00OR22725 



\section{CONTENTS}

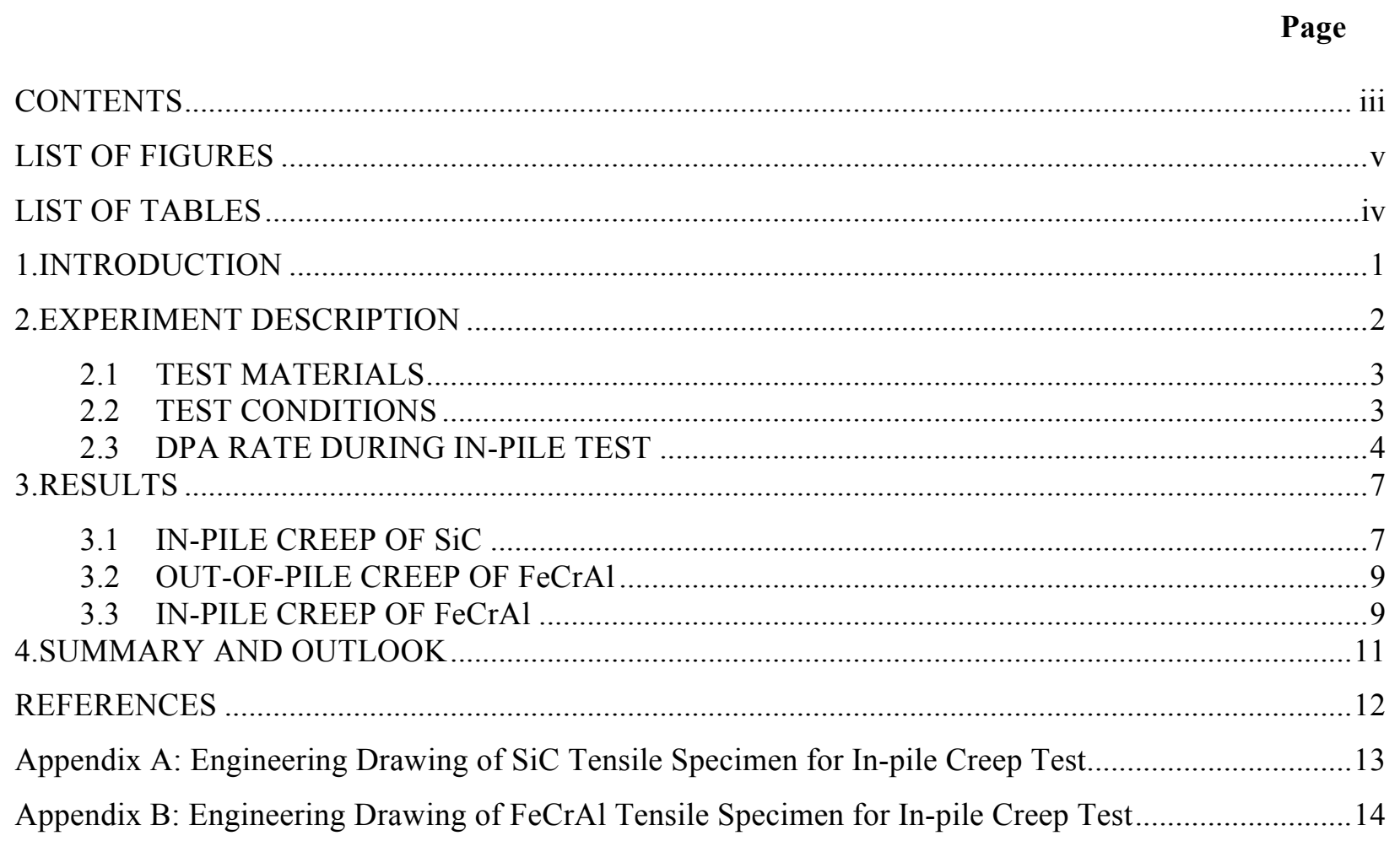





\section{LIST OF FIGURES}

Figure

Page

Fig. 1. Schematic of instrumented in-pile creep test rig. .2

Fig. 2. Neutron flux spectra per unit lethargy in Halden IFA-744 test rig and HFIR PTP position (HFIR in blue).

Fig 3. Neutron flux spectra in Halden IFA-744 test rig and HFIR PTP position.

Fig. 4. dpa cross sections in barns for $\mathrm{SiC}, \mathrm{Fe}$, and $\mathrm{Fe}-13 \mathrm{Cr}-5 \mathrm{Al}$ as a function of neutron energy in $\mathrm{MeV}$. The cross sections for $\mathrm{Fe}$ and $\mathrm{FeCrAl}$ are based on the NRT approach.

Fig. 5. Temperature, stress, and displacement as a function of neutron dose applied and experienced by $\mathrm{SiC}$ specimens.

Fig. 6. Swelling and creep strain of $\mathrm{SiC}$ samples in the Halden experiment compared with swelling data from HFIR specimens from ref [16]

Fig. 7. Instantaneous irradiation creep compliance of $\mathrm{SiC}$ measured in Halden at $300^{\circ} \mathrm{C}$ and compared with results from HFIR tests from ref. [7]. . .8

Fig. 8. Out-of-pile creep strain as a function of time on $\mathrm{FeCrAl}$ alloys.

Fig. 9. Temperature, stress, and displacement as a function of neutron dose applied and experienced by $\mathrm{FeCrAl}$ specimens. 



\section{LIST OF TABLES}

Table

Page

Table 1. Analyzed chemistry of the ORNL ATF FeCrAl alloys studied................................................

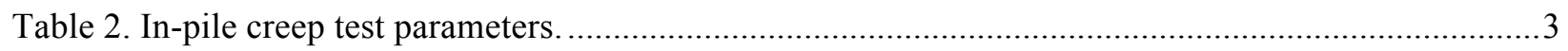

Table 3. dpa rate in $\mathrm{SiC}$ and Fe in HFIR and Halden calculated using various dpa cross

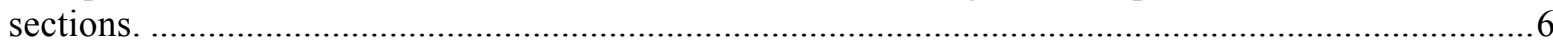

Table 4. In-pile and out-of-pile creep strain rate experienced by FeCrAl specimens. ............................ 10 



\section{INTRODUCTION}

Given their exceptional oxidation resistance in high-temperature steam environments [1-2], $\mathrm{SiC}$ and $\mathrm{FeCrAl}$ alloys are leading candidates to replace Zr-based alloys in current light water reactors (LWRs) as accident tolerant fuel cladding. The goal of this study is to perform a sensitive examination of swelling and irradiation creep behavior of $\mathrm{SiC}$ and $\mathrm{FeCrAl}$ materials. These parameters are important material properties that dictate the stress and deformation behavior of the integral fuel pin. The viability of these cladding concepts to replace Zr-based alloys is contingent on their satisfactory performance under in-pile conditions as nuclear fuel cladding. The first steps to assess their viability, is to carry out detailed thermomechanical analysis of these structures as nuclear fuel cladding using fuel performance analysis tools. Therefore, it is essential to develop an accurate understanding of swelling and creep behavior of these materials through well-controlled experiments and use them as informed inputs into these fuel performance analysis tools.

Irradiation may result in swelling or enhance creep in materials among numerous other effects [3]. Irradiation swelling strictly refers to an isotropic volume increase in an unstressed material caused by the formation of irradiation-induce defects, resulting from the agglomeration of point defects and gas atoms inside the material. Irradiation Creep refers to a slow deformation at constant volume, in a material that is subjected to a stress below the yield stress; the role of irradiation is to accelerate creep mechanisms that occur outside irradiation. From an engineering perspective, the strict definition of irradiation creep refers to the observed difference in deformation from the material under stress with and without irradiation. The total deformation strain of the material under stress in the in-pile conditions is the sum of strains due to linear swelling, thermal creep, and irradiation creep, Eq. (1).

$$
\varepsilon_{\text {total }}=\varepsilon_{\text {swelling }}+\varepsilon_{\text {thermal creep }}+\varepsilon_{\text {irradiation creep }}
$$

Swelling behavior of $\mathrm{SiC}$ has been studied extensively with comprehensive references available in the literature [4-5]. Thermal creep rate of $\mathrm{SiC}$ is insignificant at temperatures below $1400^{\circ} \mathrm{C}$ and can be ignored for LWR fuel cladding application [6]. Irradiation creep of $\mathrm{SiC}$ has received some attention and is undergoing continued investigation [7].

Swelling behavior of ferritic steels has received ample attention in the past and is known to be negligible in the dose range applicable to LWR fuel cladding [8]. Thermal creep is a strong function of alloy composition and microstructure and has received very limited attention in case of FeCrAl alloys in the temperature range of interest for LWR fuel cladding $\left(300-400^{\circ} \mathrm{C}\right)$ [9]. Finally, irradiation creep has received some attention with rough estimates available for bcc metals in the literature [8]. 


\section{EXPERIMENT DESCRIPTION}

This experiment involves in-pile creep testing of ATF FeCrAl and SiC specimens, with the aim of providing reliable in-pile data on creep compliance coefficient of these materials as a function of dose and temperature. Such data will be supportive of the qualification datapackage necessary for the eventual application of $\mathrm{FeCrAl}$ or $\mathrm{SiC}$ as a lead test rod (LTR) in a commercial LWR.

Only a limited temperature is probed that is directly applicable to the temperature of LWR fuel cladding under normal operating conditions. For $\mathrm{FeCrAl}$ alloys the test temperature was fixed at $350^{\circ} \mathrm{C}$. In case of $\mathrm{SiC}$, in order to exaggerate the swelling, the test temperature was kept constant at $300^{\circ} \mathrm{C}$. The creep tests take advantage of in-pile instrumentation and control systems native to the Halden facility to collect accurate in-pile data with reliable environmental controls. Detailed description of this test rig is provided elsewhere [10], but briefly, they utilize adjustable mixture gas flow in annular regions of the capsule, coupled with multiple thermocouples in each capsule for precise temperature control along the length of the specimen. The stress on the creep specimens is controlled by direct gas pressure control inside a bellow attached to the creep specimen that is gripped at the other end. The creep strain is measured directly using a calibrated linear variable differential transformer (LVDT) that is in contact with the end of the specimen. Figure 1 shows a schematic of the in-pile creep test rig.

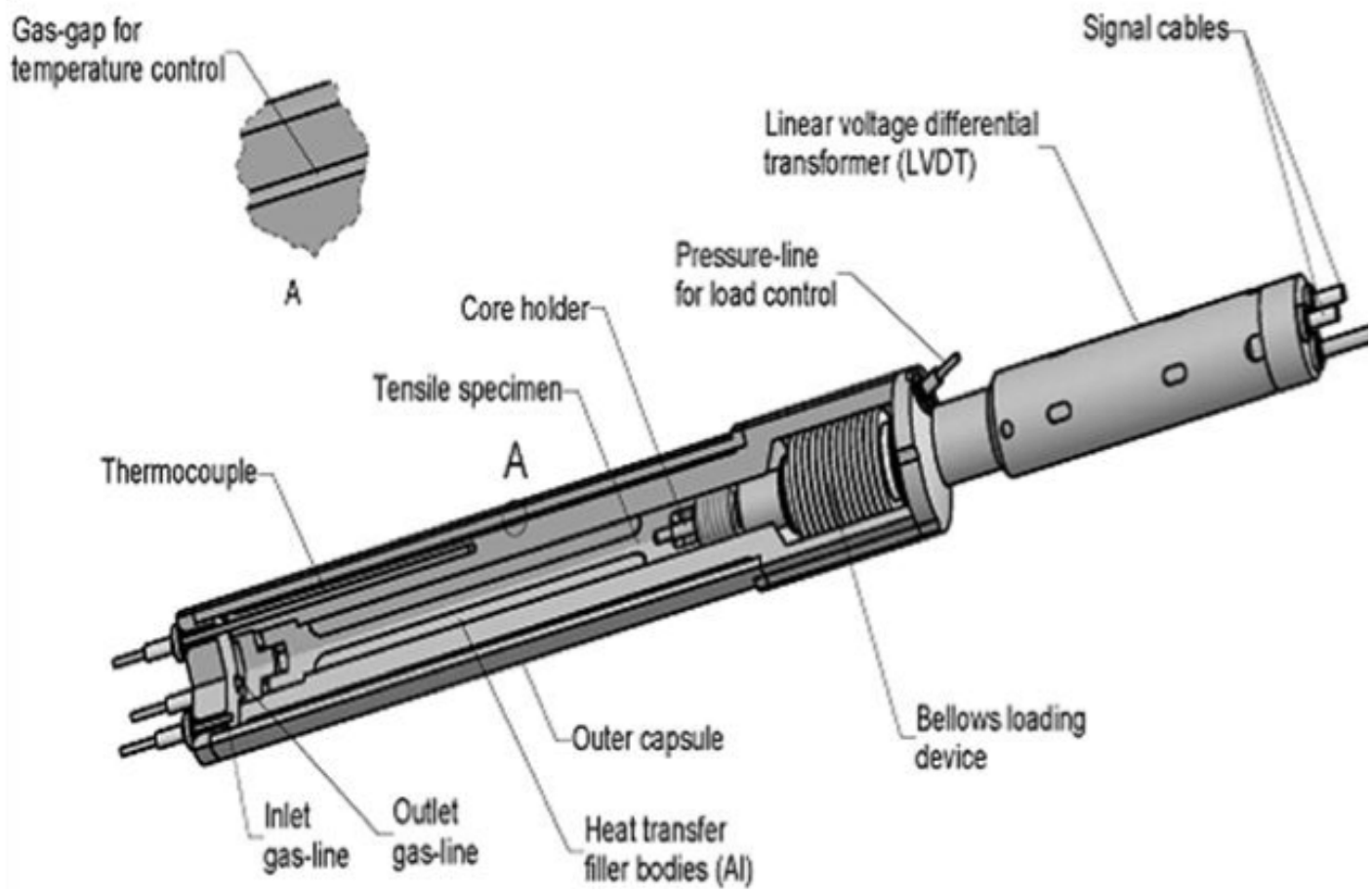

Fig. 1. Schematic of instrumented in-pile creep test rig from ref. [10]. 


\subsection{TEST MATERIALS}

Two SiC specimens machined from high-purity chemical vapor deposited (CVD) SiC were examined in this study. The CVD variant, of purity $>99.999 \%$, was purchased from Dow Chemical Co. (Marlborough, MA). Also, three FeCrAl specimens from two distinct alloys were examined. The FeCrAl alloys were produced at ORNL and they were designated as C35M2 and C35MN5. The composition of the alloys is provided in Table 1. C35M2 alloy was hot-forged at $650^{\circ} \mathrm{C}$ with $75 \%$ area reduction $(36 \mathrm{~mm}$ diameter round bar to $16 \mathrm{~mm}$ square bar), followed by annealing at $650^{\circ} \mathrm{C}$ for $1 \mathrm{~h}$. Microstructure of this alloy consisted of deformed (elongated) grains. Note that the final annealing was applied to stabilize fine subgrain (SG) structure, with $\sim 1-5 \mu \mathrm{m}$ size inside of the elongated grains. C35MN5 alloy was hot-extruded at $800^{\circ} \mathrm{C}$ with $88 \%$ area reduction $\left(2.9\right.$ " diameter to $1.0^{\prime \prime}$ diameter), followed by annealing at $800^{\circ} \mathrm{C}$ for $1 \mathrm{~h}$. Microstructure consists of highly deformed (elongated) grains, which shows a dense dispersion of Nb-rich second-phase precipitates. Extensive detail on processing and properties of these alloys is provided elsewhere [11].

Table 1. Analyzed chemistry of the ORNL ATF FeCrAl alloys studied

\begin{tabular}{|c|c|c|c|c|c|c|c|c|c|c|c|}
\hline \multirow{2}{*}{ Heat } & \multicolumn{11}{|c|}{ Analyzed composition [wt $\%]$} \\
\hline & $-\mathrm{Fe}$ & $\mathrm{Cr}$ & $-\mathrm{Al}$ & Mo & $-\mathrm{Si}$ & $-\mathrm{Nb}$ & $-\mathrm{Y}$ & C & $-\mathrm{N}$ & $\mathrm{O}$ & $-\underline{S}$ \\
\hline $\mathrm{C} 35 \mathrm{M} 2$ & 79.67 & 13.06 & 5.15 & 1.97 & 0.12 & - & 0.010 & 0.004 & 0.0021 & 0.0017 & 0.0015 \\
\hline $\mathrm{C} 35 \mathrm{MN} 5$ & 78.68 & 13.02 & 5.08 & 1.99 & 0.21 & 0.97 & 0.032 & 0.003 & 0.0013 & 0.0028 & 0.0003 \\
\hline
\end{tabular}

\subsection{TEST CONDITIONS}

Tensile specimens from the materials described were produced for this test. The exact drawings for the $\mathrm{FeCrAl}$ and $\mathrm{SiC}$ tensile specimens are provided at the end of this document as appendices. The specimens were tested in the stress-free and stressed conditions to determine the swelling-induced deformation only, as well as the swelling and creep-induced deformations combined. Note that a small stress $(\sim 5 \mathrm{MPa})$ was applied under the stress-free conditions to ensure the specimen is in good contact with the LVDT. The test conditions are described in Table 2. Note that the stress on the SiC specimen was and remains maintained at $100 \mathrm{MPa}$. However the stress level on the $\mathrm{FeCrAl}$ specimens is varied over time to determine the creep rate as a function of stress. Also, since thermal creep may not be ignored for FeCrAl alloys, a separate series of out-of-pile creep tests at the exact temperature and stress levels were carried out at ORNL. In this manner the magnitude of thermal creep could be determined separately. The starting stress for FeCrAl alloys was set at a high value of $325 \mathrm{MPa}$ that is just below the yield stress of these alloys at $350^{\circ} \mathrm{C}$. This stress is representative of a value that is expected to develop in the thin cladding under fuel pin operation, particularly upon fuel-pellet contact.

Table 2. In-pile creep test parameters.

\begin{tabular}{ccccccccc}
\hline Specimen & Temperature $\left[{ }^{\circ} \mathrm{C}\right]$ & \multicolumn{7}{c}{ Stress [MPa] } \\
\hline C35MN5C-1 & 350 & 325 & 300 & 250 & 200 & 100 & 350 & 325 \\
\hline C35M2-1 & 350 & 325 & 300 & 250 & 200 & 100 & 350 & 325 \\
\hline C35M2-2 & 350 & \multicolumn{7}{c}{000} \\
\hline SiC-1 & 300 & \multicolumn{7}{c}{000} \\
\hline SiC-2 & 300 & \multicolumn{7}{c}{0} \\
\hline
\end{tabular}




\subsection{DPA RATE DURING IN-PILE TEST}

Since irradiation creep is directly proportional to the damage induced in the material as a result of neutron fluence, it is essential to perform accurate calculation of damage production rate in these materials. This is particularly important when the results from the tests in a research reactor are to be compared with results from other research reactors or applied to predict the material behavior in commercial reactors. In order to perform dpa calculations, flux spectrum (flux per unit energy, $\varphi_{g}[E]$ ) that is experienced by the specimen is necessary. The total flux, $\phi$, is the sum of the flux in each energy group. Flux spectra for HFIR (in the flux trap target (FTT) peripheral target position (PTP) at the midplane location) and Halden (IFA-744 rig at the location of creep capsules), are shown in Figure 2 and 3, where the former is normalized per unit lethargy. The total flux for the HFIR and Halden positions is $4.46 \times 10^{15}$ and $1.20 \times 10^{14} \mathrm{n} / \mathrm{cm}^{2}-\mathrm{s}$, respectively. However, the spectra differ significantly, as shown in Fig. 2 where fast flux is roughly two orders of magnitude larger in HFIR.

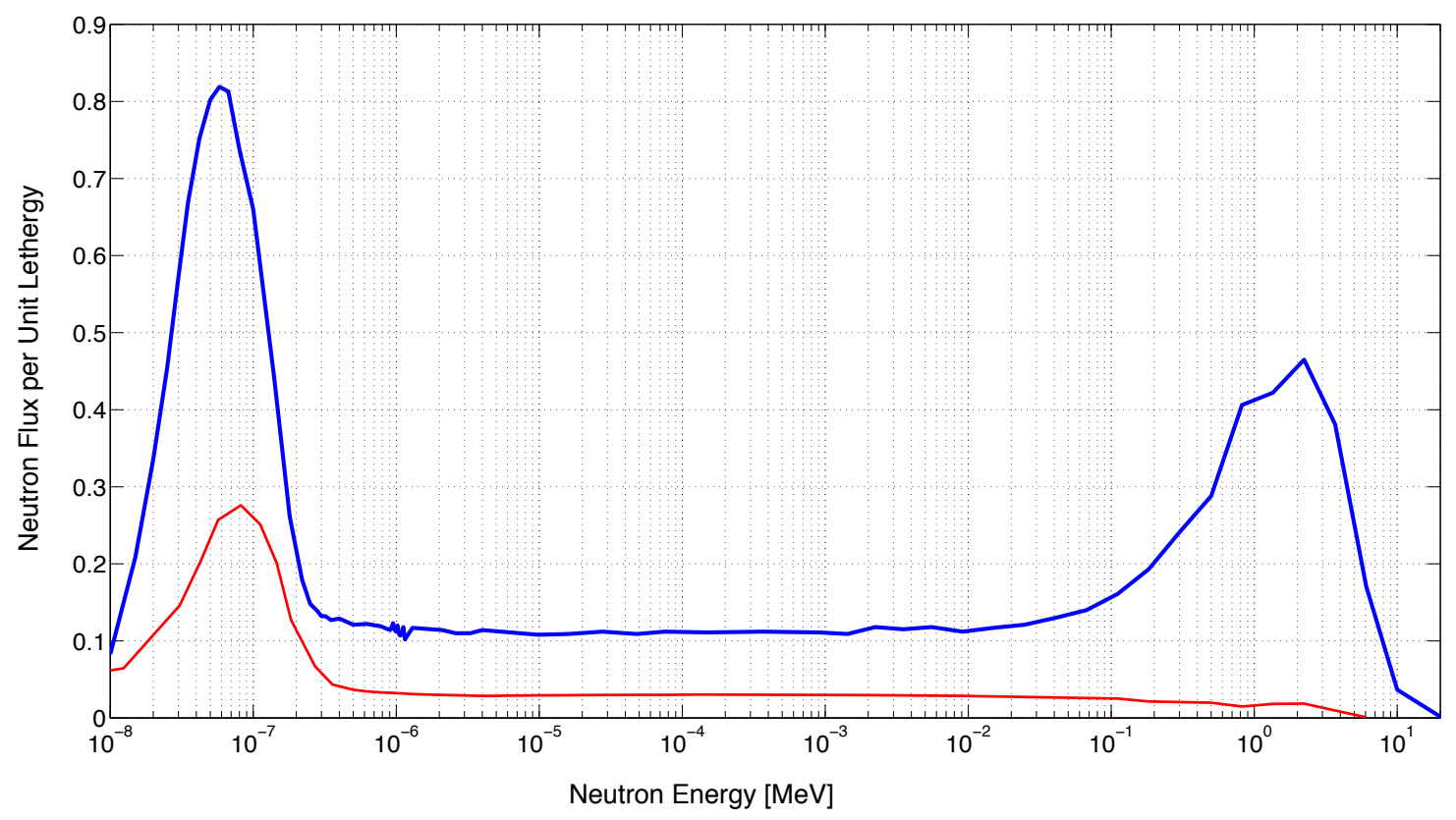

Fig. 2. Neutron flux spectra per unit lethargy in Halden IFA-744 test rig and HFIR PTP position (HFIR in blue).

The goal is to calculate the dpa (displacement per atom) rate in the materials of interest. The dap rate can be calculated as:

$$
\dot{d}=\int \varphi_{g}(E) \sigma_{d}(E) d E
$$

where $\sigma_{d}$ is the displacement cross section. The displacement cross section for SiC [12] and pure Fe [13] are shown in Fig. 4. Also shown is the dpa cross section for Fe-13Cr-5Al alloy, calculated simply by weighing in the mole fraction of $\mathrm{Cr}$ and $\mathrm{Al}$ in the alloy and accounting for their dpa cross section from the same reference as for pure Fe. Note that the dpa cross section for the alloy was binned differently than that of pure Fe (larger energy bins) and appears smoother than the Fe dpa cross section. 
The calculation in Eq. (2) was carried out using numerical methods and the dpa rate for these materials in Halden's IFA 744 and HFIR's FTT-PTP was estimated. The results are tabulated in Table 3. These results were also compared with the output from the SPECTER code [14] and they were in good agreement.

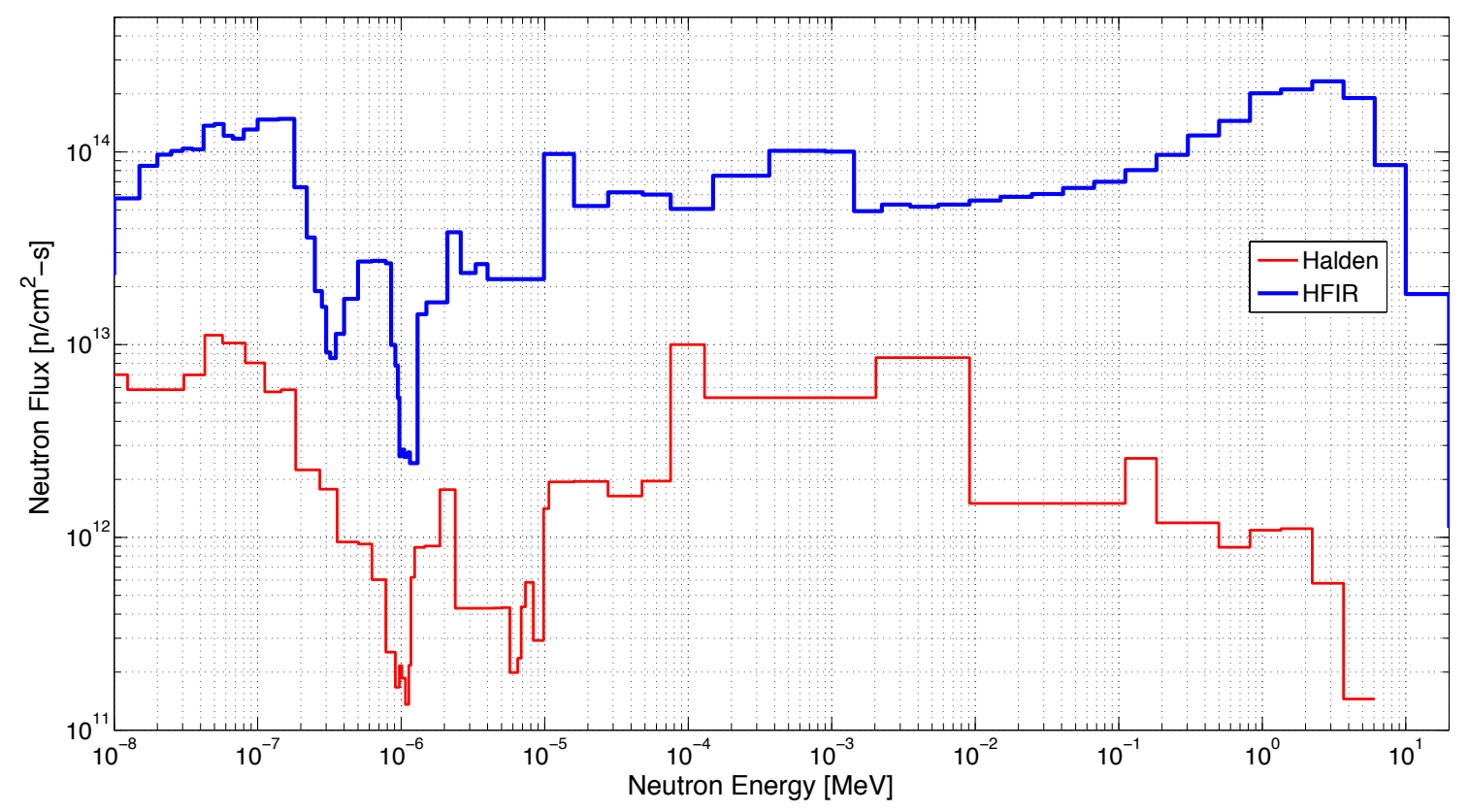

Fig 3. Neutron flux spectra in Halden IFA-744 test rig and HFIR PTP position.

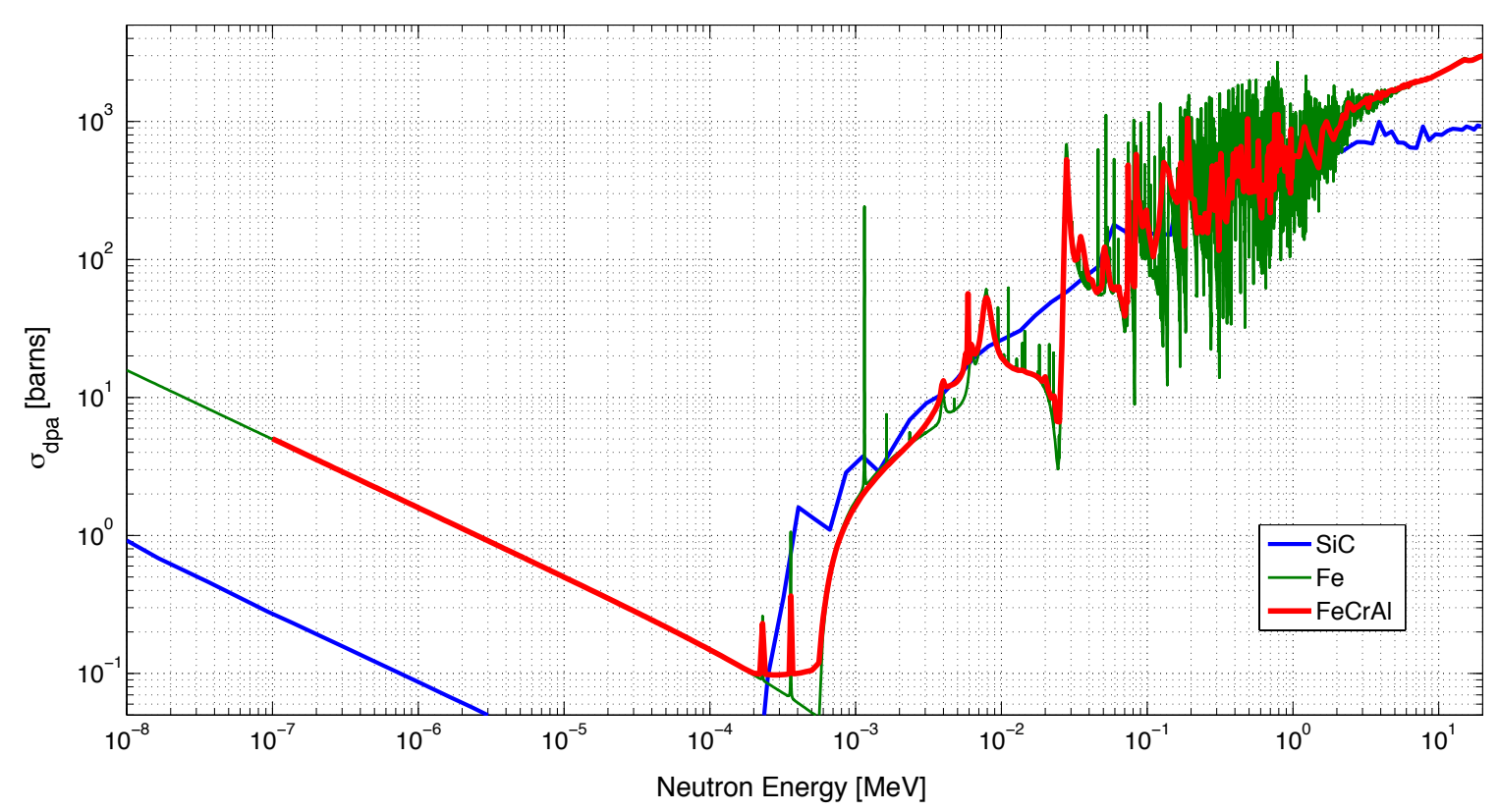

Fig. 4. dpa cross sections in barns for $\mathrm{SiC}, \mathrm{Fe}$, and $\mathrm{Fe}-13 \mathrm{Cr}-5 \mathrm{Al}$ as a function of neutron energy in $\mathrm{MeV}$. The cross sections for $\mathrm{Fe}$ and $\mathrm{FeCrAl}$ are based on the NRT approach. 
Table 3. dpa rate in $\mathrm{SiC}$ and Fe in HFIR and Halden calculated using various dpa cross sections

\begin{tabular}{|c|c|c|c|c|c|}
\hline & $\mathrm{dpa} / \mathrm{s}$ & dpa/HFIR ${ }^{1}$ Cycle & dpa/month & $\mathrm{dpa} / 1000 \mathrm{~h}$ & dpa/EFPY \\
\hline \multicolumn{6}{|c|}{ CVD-SiC - dpa cross section from [12] } \\
\hline Halden IFA 744 & $3.59 \mathrm{E}-09$ & & 0.009 & 0.013 & 0.113 \\
\hline HFIR FTT-PTP & 7.59E-07 & 1.57 & 1.97 & 2.73 & 23.84 \\
\hline \multicolumn{6}{|c|}{ Pure Fe-NRT ${ }^{2}$} \\
\hline Halden IFA 744 & 4.94E-09 & & 0.013 & 0.018 & 0.155 \\
\hline HFIR FTT-PTP & $9.53 \mathrm{E}-07$ & 1.98 & 2.47 & 3.43 & 29.94 \\
\hline \multicolumn{6}{|c|}{ FeCrAl - NRT ${ }^{2}$} \\
\hline Halden IFA 744 & 4.63E-09 & & 0.012 & 0.017 & 0.145 \\
\hline HFIR FTT-PTP & $1.05 \mathrm{E}-06$ & 2.18 & 2.72 & 3.78 & 32.99 \\
\hline
\end{tabular}

${ }^{1}$ HFIR cycle of 24 days is assumed.

${ }^{2}$ NRT $\rightarrow$ Norget-Robinson-Torrens [15]. 


\section{RESULTS}

\subsection{IN-PILE CREEP OF SiC}

Figure 5 shows the results from in-pile measurement of displacement in $\mathrm{SiC}$ specimens along with the exact levels of applied stress and continuous measurement of temperature. The figure plots the highquality displacement dataset as function of dose. A clear and significant departure in strain rate between the two samples is observed upon application of $100 \mathrm{MPa}$ of stress on one of the specimens. Figure 6 compares the swelling and creep strain experienced by these specimens with discrete swelling strain data from specimens irradiated in HFIR where the two appear to be in good agreement.

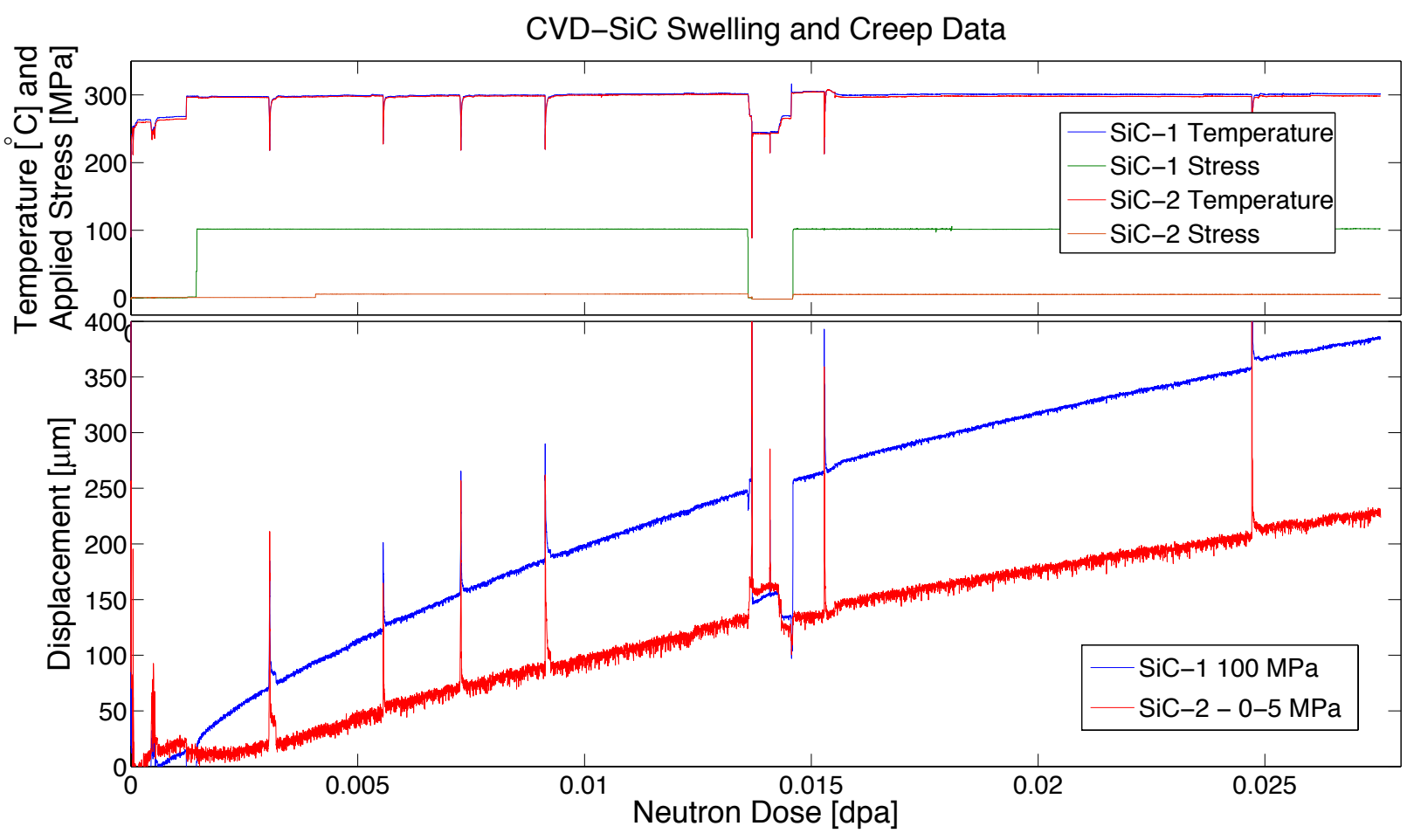

Fig. 5. Temperature, stress, and displacement as a function of neutron dose applied and experienced by SiC specimens.

As the described in Eq. (3), The difference in the instantaneous strain rate of stressed and stress-free SiC specimens, normalized per unit stress, is the instantaneous irradiation creep compliance of $\mathrm{SiC}$.

$$
\dot{\varepsilon}_{\text {irradiation creep }}=\frac{\dot{\varepsilon}_{\text {stressed }}-\dot{\varepsilon}_{\text {swelling }}}{\sigma}
$$

The irradiation creep compliance is plotted as function of neutron dose in Fig. 7 and it appears to follow logarithmic creep behavior within this dose range. It is also compared with irradiation creep compliance data from bend stress relaxation (BSR) tests in HFIR [7]. The creep compliance measured here appears significantly larger than the prior HFIR results. The reason for this difference is not yet fully understood and may be partially due to the different grain boundary type and distribution between the two specimens used in these two separate tests. The large difference in the dose rate between these two irradiation experiments may also play an important role to result in this discrepancy. 


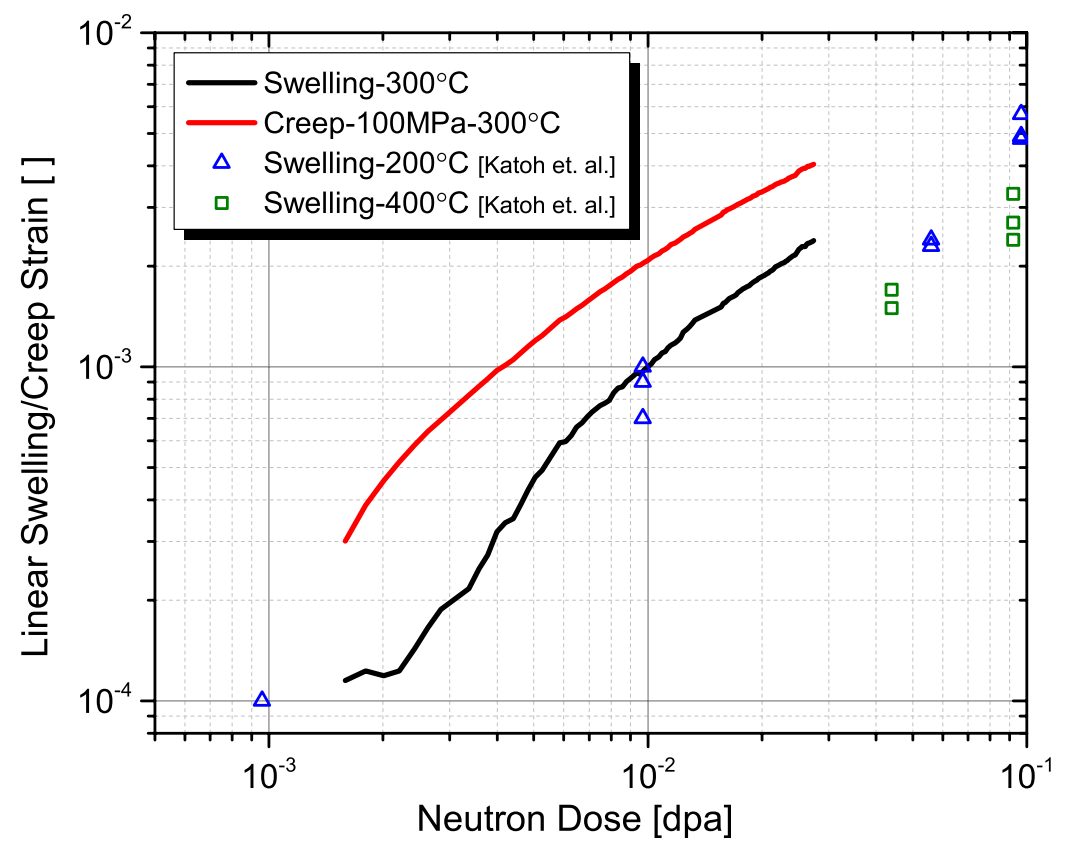

Fig. 6. Swelling and creep strain of SiC samples in the Halden experiment compared with swelling data from HFIR specimens from ref [16].



Fig. 7. Instantaneous irradiation creep compliance of $\mathrm{SiC}$ measured in $\mathrm{Halden}$ at $300^{\circ} \mathrm{C}$ and compared with results from HFIR tests from ref. [7]. 


\subsection{OUT-OF-PILE CREEP OF FeCrAl}

Out-of-pile creep tests were performed on unirradiated FeCrAl specimens from the same exact batch of materials that was tested in Halden in irradiation creep capsules. The purpose of the out-of-pile tests was to separately determine the thermal creep rate in these alloys to then be able to distinguish all the distinct terms on the right-hand-side of Eq. (1). The tests were conducted at $350^{\circ} \mathrm{C}$ in an inert atmosphere on the C35M2 and C35MN5C alloys. The out-of-pile creep strain as a function of time is plotted in Figure 8. The thermal creep rate measured here for these alloys appears to be significantly (2-3 orders of magnitude) larger than the limited set of data reported in the literature for FeCrAl alloys at higher temperatures [9].
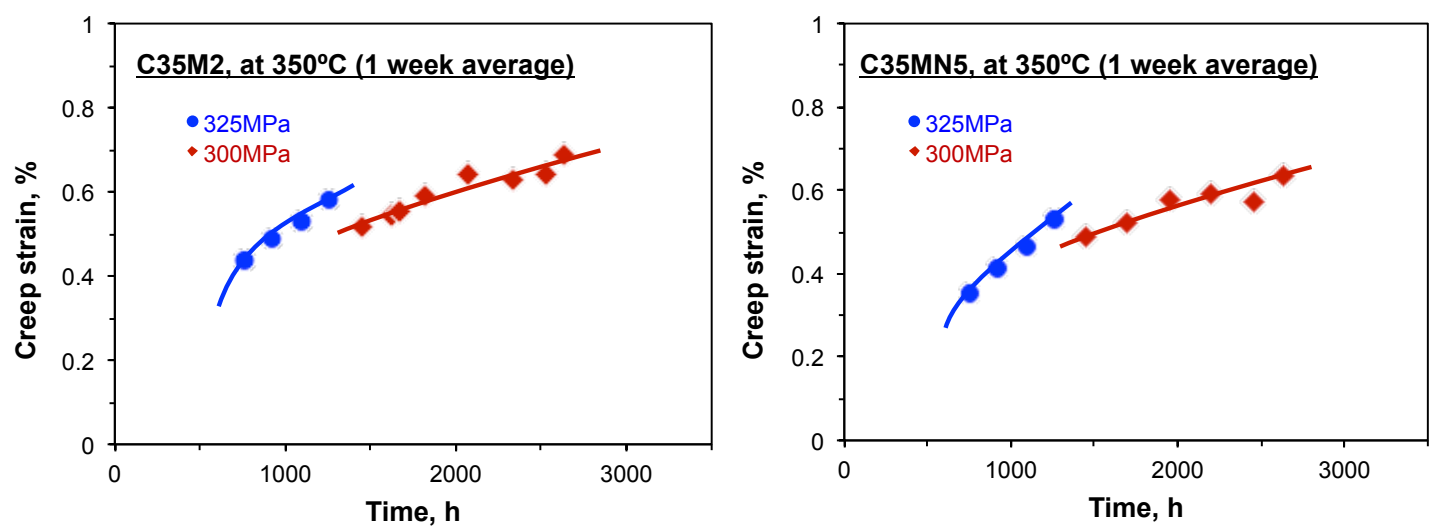

Fig. 8. Out-of-pile creep strain as a function of time on FeCrAl alloys.

\subsection{IN-PILE CREEP OF FeCrAl}

Figure 9 shows the results from in-pile measurement of displacement in $\mathrm{FeCrAl}$ specimens along with the exact levels of applied stress and continuous measurement of temperature. The figure plots the displacement dataset as function of dose. A clear and significant departure in strain rate between the stressed and stress-free C35M samples is observed upon application of $325 \mathrm{MPa}$ of stress on one of the specimens. In fact, within the dose range experienced by the C35M alloy, no swelling strain can be discerned in the stress-free sample. This is consistent with what is expected in ferritic alloys within this dose regime and up to at least a few tens of dpa (beyond what is expected within their lifetime as LWR fuel cladding) [8]. The displacement data for C35MN specimen appears unreliable and may hint at sensor failure during the test. Therefore, further analysis of the displacement data for this alloy is neglected.

Table 4 provides a comparison between the in-pile and out-of-pile creep strain rate experienced by these specimens. The out-of-pile and in-pile data are in very good agreement for the C35M alloy. This is indicative of the small relative magnitude of irradiation creep when compared with the thermal creep rate in this alloy. This is consistent with the estimates in the literature where irradiation creep in bcc metals is on the order of $0.5 \times 10^{-6} \mathrm{MPa}^{-1} \mathrm{dpa}^{-1}[8]$. 


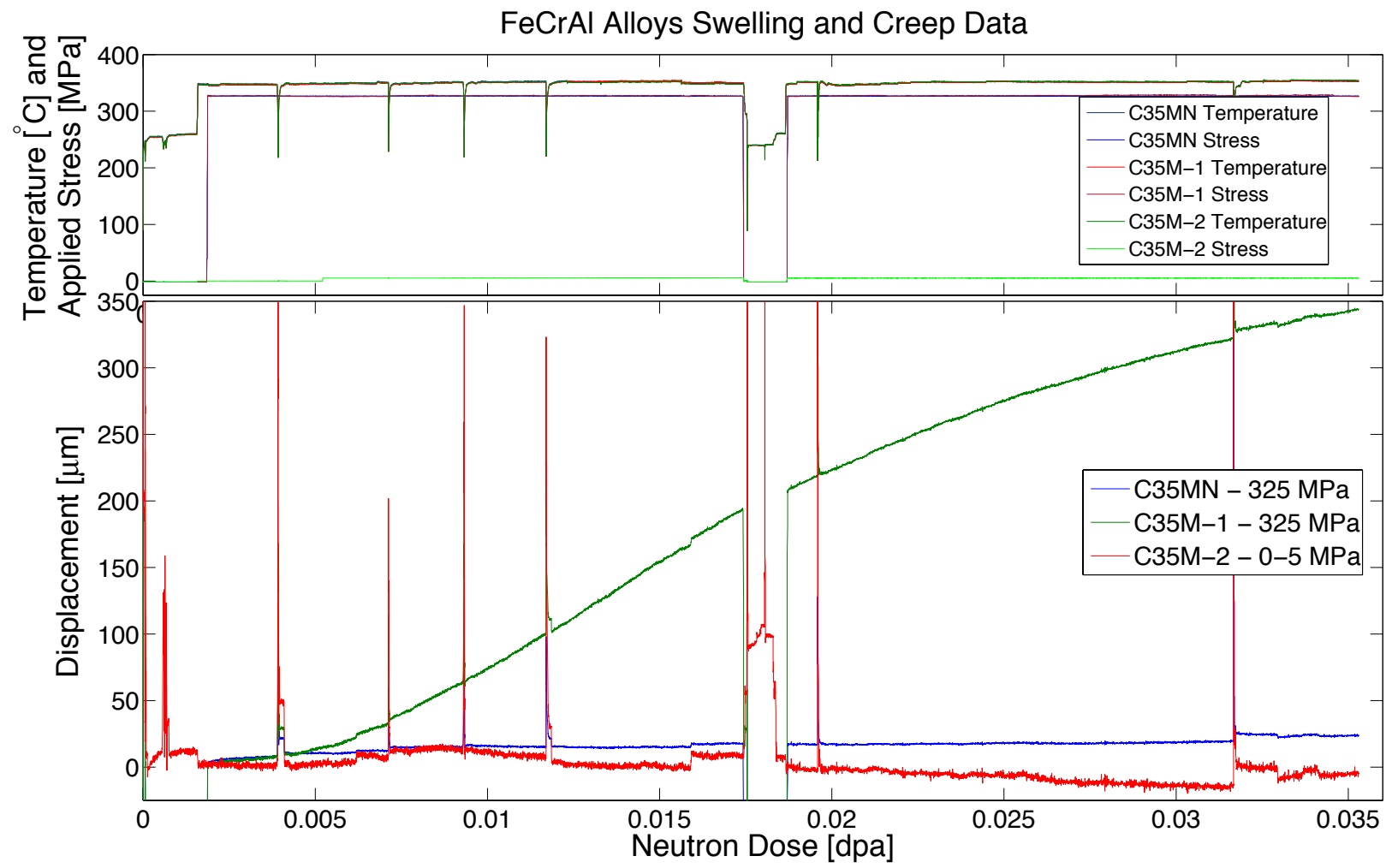

Fig. 9. Temperature, stress, and displacement as a function of neutron dose applied and experienced by FeCrAl specimens.

Table 4. In-pile and out-of-pile creep strain rate experienced by FeCrAl specimens

\begin{tabular}{cccc}
\hline Alloy & Stress [MPa] & Dose [dpa] Creep strain rate $\left[\mathrm{h}^{-1}\right]$ \\
\hline \multirow{4}{*}{ C35M } & 325 & 0 & $2.9 \times 10^{-6}$ \\
\cline { 2 - 4 } & 300 & 0 & $1.2 \times 10^{-6}$ \\
\cline { 2 - 4 } & & 0.007 & $2.4 \times 10^{-6}$ \\
\cline { 2 - 4 } & 325 & 0.012 & $3.7 \times 10^{-6}$ \\
\cline { 2 - 4 } C35MN & & 0.030 & $1.6 \times 10^{-6}$ \\
\cline { 2 - 4 } & 325 & 0 & $3.4 \times 10^{-6}$ \\
\hline \multirow{2}{*}{} & 300 & 0 & $1.0 \times 10^{-6}$ \\
\hline
\end{tabular}




\section{SUMMARY AND OUTLOOK}

A set of in-pile creep tests is ongoing in the Halden reactor on ORNL's candidate accident tolerant fuel cladding materials. These tests are meant to provide essential material property information that is needed for an informed analysis of these fuel concepts under normal operating conditions. These tests provide detailed information regarding swelling, thermal creep, and irradiation creep rates of these materials. The results to date have been compared with the limited set of information available in literature that is form irradiation tests in other reactors or out-of-pile tests. Most of the results are in good agreement with prior literature, except for irradiation creep rate of $\mathrm{SiC}$. To elucidate the difference between the HFIR and Halden test results continued testing is necessary. The tests describe in this progress report are ongoing and will continue for at least another year. 


\section{REFERENCES}

[1] K. A. Terrani; B. A. Pint; C. M. Parish; C. M. Silva; L. L. Snead; Y. katoh, Journal of American Ceramic Society 2014, 97 (8), 2331-2352.

[2] B. A. Pint; K. A. Terrani; M. P. Brady; T. Cheng; J. R. Keiser, Journal of Nuclear Materials 2013, 440, 420-427.

[3] D. R. Olander, Fundamental Aspects Of Nuclear Reactor Fuel Elements. Technical Information Center: Springfield, VA, 1976; p 1-566.

[4] Y. Katoh; K. Ozawa; C. Shih; T. Nozawa; R. J. Shinavski; A. Hasegawa, et al., Journal of Nuclear Materials 2014, 448, 448-476.

[5] L. L. Snead; T. Nozawa; Y. Katoh; T. S. Byun; S. Kondo; D. A. Petti, Journal of Nuclear Materials 2007, 371 (1-3), 329-377.

[6] C. CARTER; R. DAVIS; J. BENTLEY, Journal of the American Ceramic Society 1984, 67 (11), 732-740.

[7] Y. Katoh; L. L. Snead; C. M. Parish; T. Hinoki, Journal of Nuclear Materials 2013, 434 (1), 141-151.

[8] F. A. Garner; M. B. Toloczko; B. H. Sencer, Journal of Nuclear Materials 2000, 276, 123-142.

[9] S. Saunders; H. Evans; M. Li; D. Gohil; S. Osgerby, Oxidation of metals 1997, 48 (3-4), 189-200.

[10] J. P. Foster; T. M. Karlsen Update of Irradiation Creep and Irradiation Stress Relaxation of 316 and 304L Stainless Steel, HWR-1047; OECD Halden Reactor Project: 2013.

[11] Y. Yamamoto; B. A. Pint; K. A. Terrani; K. G. Field; Y. Yang; L. L. Snead, Journal of Nuclear Materials 2015, submitted.

[12] H. L. Heinisch; L. R. Greenwood; W. J. Weber; R. E. Williford, Journal of nuclear materials 2004, 327 (2), 175-181.

[13] A. Konobeyev; U. Fischer; L. Zanini In Advanced evaluations of displacement and gas production cross sections for chromium, iron, and nickel up to $3 \mathrm{GeV}$ incident particle energy, Proceedings of the 10th International Topical Meeting on Nuclear Applications and Utilization of Accelerators, AccApp11. Knoxville, TN, US, 2011.

[14] L. R. Greenwood; R. K. Smither SPECTER: Neutron Damage Calculations for Materials Irradiations, ANL/FPP/TM-197; Argonne National Laboratory: 1985.

[15] M. J. Norgett; M. T. Robinson; I. M. Torrens, Nuclear Engineering and Design 1975, 33, 50-54.

[16] Y. Katoh; T. Nozawa; L. L. Snead; K. Ozawa; H. Tanigawa, Journal of Nuclear Materials 2011, $417(1-3), 400-405$. 
Appendix A: Engineering Drawing of SiC Tensile Specimen for In-pile Creep Test

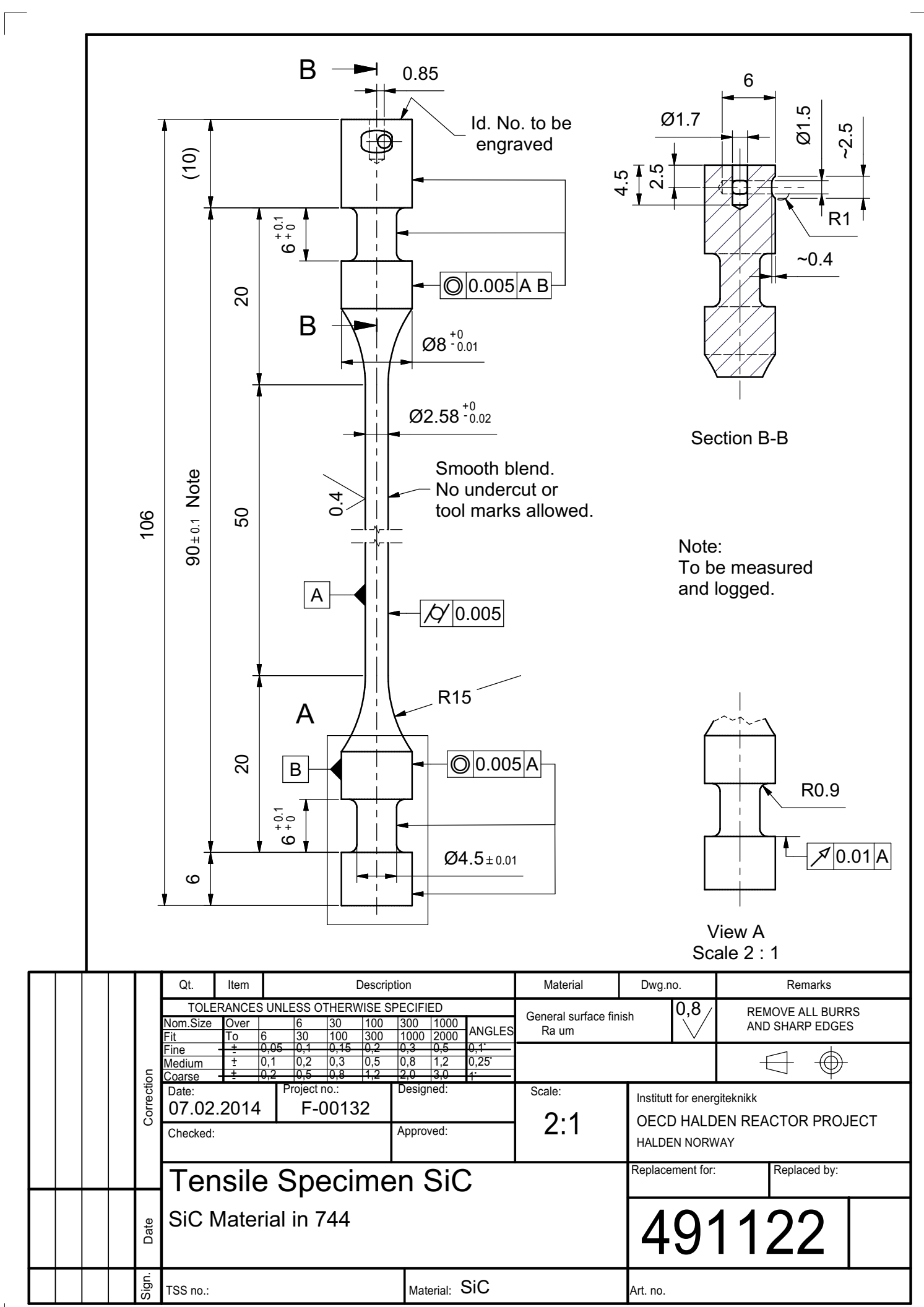


Appendix B: Engineering Drawing of FeCrAl Tensile Specimen for In-pile Creep Test

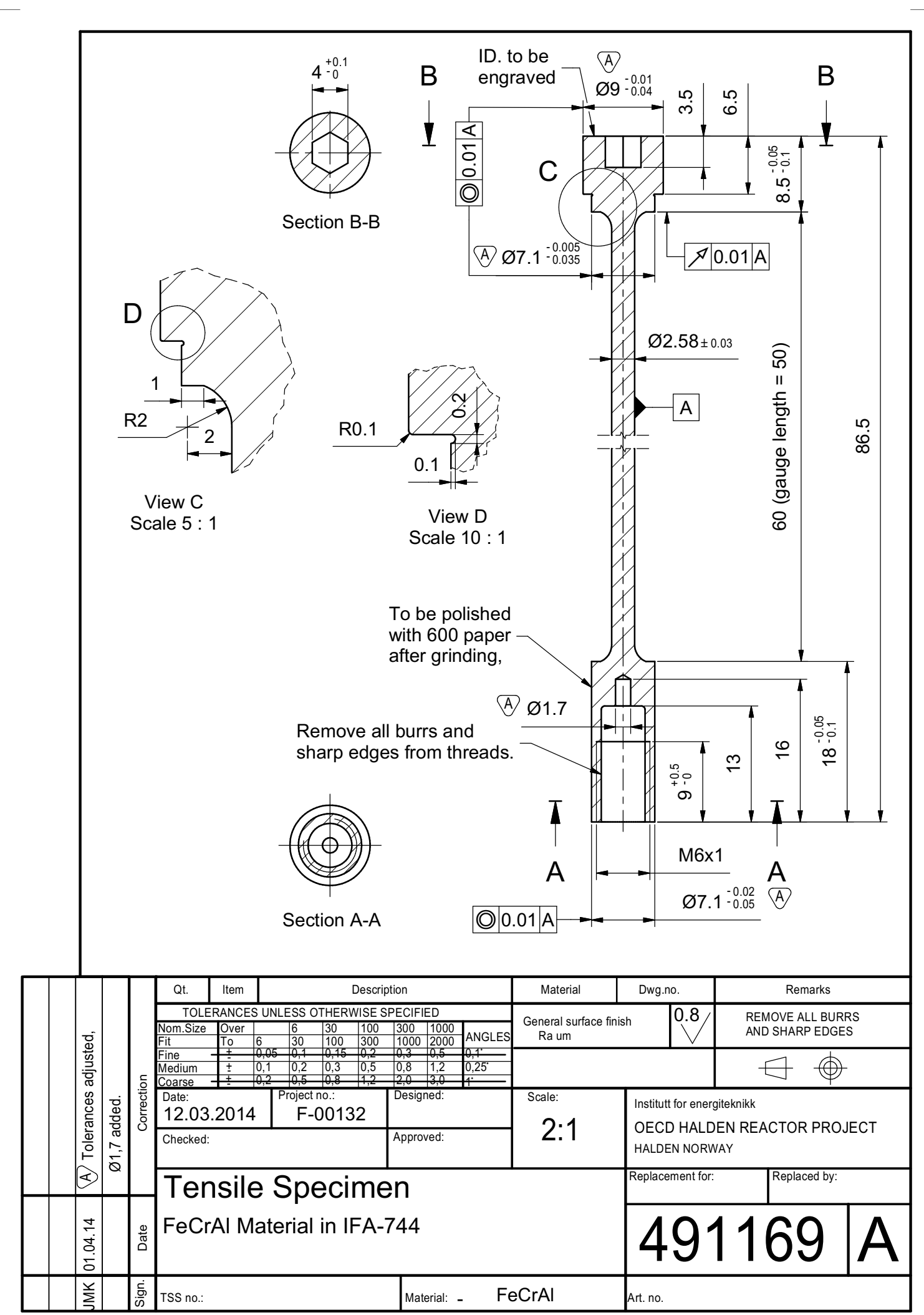


